\title{
The Effectiveness of Video Trackers in Understanding Viscosity Concepts
}

\author{
Nenik Yuniarti ${ }^{1}$, Linuwih ${ }^{2}, \mathrm{~S}$, Sulhadi $^{3}$ \\ ${ }^{1}$ SMA Negeri 2 Pekalongan \\ ${ }^{2,3}$ Graduate School, Universitas Negeri Semarang, Indonesia \\ ${ }^{1}$ Correspoding email: nenikguritno.sma2@gmail.com
}

\begin{abstract}
The paradigm of constructivism has characteristics such as learning with experimental activity, questions, investigations, hypotheses, and models produced by the students themselves through the experience they gain. Selection of appropriate teaching methods by teachers is expected to create pleasant learning atmosphere, avoid boredom, and create interactive, effective, as well as efficient learning conditions. One of the chosen learning methods is tracker video to improve understanding of the concept of viscosity. The purpose of this research is to investigate the effectiveness of tracking video to understand the concept of viscosity. The learning method in the control class was manual viscosity practicum using stopwatch while experiment class used with video tracker. The post-test average value of the control class and experiment class had significant differences so that the video tracker was effective to understand the concept of viscosity. Key words: video trackers, viscosity concepts
\end{abstract}

\section{Introduction}

The constructivist paradigm has the priority of learning characterized by the experiments, questions, investigations, hypotheses, and models produced by the students themselves through the experiences they gain from learning (Anugrahaini, Nugroho, and Yulianto, 2017). The challenge for a teacher is to choose the right learning method so that it can create pleasant learning environment, avoid boredom and create interactive and effective learning conditions (Setyorini, Sukiwo, and Subali, 2012).

Cooperative learning is one of the alternatives to explore boredom during the learning process because can learners interact with members of their group (Riyadi and Mosik, 2014). Learners communicate with others to create pleasant learning environment (Linuwih and Sukwati, 2014). Cooperative learning methods can provide hands-on experience in laboratory experiments (Wahyuni, 2015).

Tracker modeling designed within the framework of Java applications by the Open Source Physics Project can be used in physics education and a mix of alternative technologies and laboratory experiments (Brown and Christian, 2011). The results obtained from the tracking process are interpreted in the form of graphs and tables making it easier for participants to analyze data on experiments in physics laboratories (Habibulloh, 2014).

Understanding the concept of fluid viscosity can be enhanced by involving the learner directly on observations and experiments (Karsumi, 2012).

Video trackers can assist in the viscosity of the practicum imagery. The movement of the spheres that fall on the liquid cannot be clearly observed in the practice of viscosity because the ball is moving too fast (Fuller, 1987). The tracking process can record balls that fall on the viscosity of the liquid (Oktova, 2013).

Graphs and tables can be interpreted into several variations according to what will be searched. The learners will be easier to determine the terminal velocity and calculate the fluid viscosity coefficient. The purpose of this study is to determine whether the use of an effective video tracker was able to improve understanding of the concept of viscosity.

\section{Methods}

The method used was mixed method sekuensial eksplanatori and research design of control group pretest-posttest. The sample selection was done by method cluster random sampling. Research began by giving a pretest. Fluid viscosity experiments were administered in two different classes using stopwatch and video tracker. This study ended with posttest delivery in the control class and experiment class.

During the lessons learners were divided into groups (Qudsi, 2014). Those groups leart to interact and work together to achieve a specific goal or task. Each group had to work on one laptop that had software tracker 
installed. The tracking software has been used from scratch so that participants could directly use their usage instructions.

The experiments were conducted with small, medium and large marbles. The tape was moved to the laptop and opened using a video tracker and then clicked the movement of the ball to fall in the liquid as was done in the study (Kaewsutthi and Wattanakasiwich, 2011). They should follow the footprints carefully, because the marbles had similar color as the liquid. The result of dragging the fall of the ball were processed and displayed in the form of data in tables and graphs, shown in figure 1.

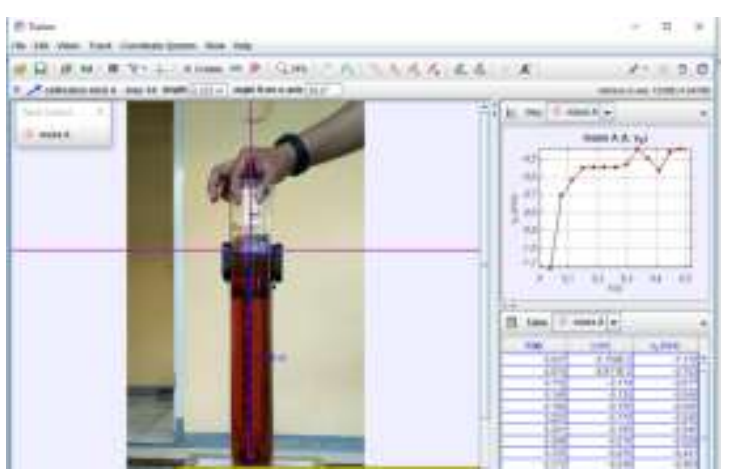

Figure 1. Display software video tracker analysis

\section{Results and Discussion}

Pretest and posttest values were used to measure the level of intelligence of learners. the result of that value is shown as follows.

Table 1. Average value of pretest - posttest control and experiment classes

\begin{tabular}{ccc}
\hline Average & $\begin{array}{c}\text { Control } \\
\text { classes }\end{array}$ & Experiment classes \\
\hline Pretest & 30,7 & 33,5 \\
Posttest & 61,5 & 77,9 \\
\hline
\end{tabular}

Differences in mean values of control and posttest of experimental class can be calculated using t-test. The result of understanding the concept of viscosity based on t-test is obtained as follows.

Table 2. T-test results of control and experiment class

\begin{tabular}{cccccc}
\hline Classes & Av. & dk & t $_{\text {count }}$ & table & Criteria \\
\hline Control & 61,47 & & & & There is a \\
Experiment & 77,93 & & 7,094 & 2,045 & difference \\
\hline
\end{tabular}

The result of $t$ test in Table 2 shows that tcount is bigger than ttable which means $\mathrm{HO}$ is rejected, and $\mathrm{Ha}$ is accepted. The Alternative Hypothesis (Ha) is accepted to show that the understanding of the concept of the experimental class is more effective than the control class.

The gain test was used to find out the large increase in students' experimental understanding and control classes processed from pretest and posttest value data. The results of income test are shown in Table 3.

Table. 3 Result of N-gain test of control class and experiment

\begin{tabular}{lll}
\hline Average & $\begin{array}{l}\text { Control } \\
\text { classes }\end{array}$ & $\begin{array}{l}\text { Experiment } \\
\text { classes }\end{array}$ \\
\hline Pretest & 30,60 & 33,52 \\
Posttest & 61,5 & 77,9 \\
Gain & 0,44 & 0,67 \\
criteria & medium & medium \\
\hline
\end{tabular}

The result of the gain test in Table 3 shows improvement of understanding of the concept of experimental class 0,67 and control class 0,44 although it is still in medium category. Being viewed from the results of testing the hypothesis and getting the value, then the use of video tracker on effective learning is used to improve the understanding of physics concepts.

Learning to understand is high-thinking learning. Interviews with lower group learners provide data that they were initially confused by using video tracking software despite being guided by teachers and instruction manuals. The division of working groups facilitates the delivery of materials with video trackers because learners can optimize peer tutors.

Peer teaching was done by empowering the ability of the students who had high absorption. The students taught material to their friends who did not understand. Students from the upper groups would transfer knowledge to the lower groups. Sources of data from moderate groups, they can follow regular learning with teacher guides and instructions on using video trackers. The results of interview with upper group provides information. They were very happy and gave good response. They gained new experiences by using video trackers on viscosity practices.

Learning by using visual aids gave students the opportunity to actively learn (Prasetyarini, Fatmaryanti, and Akhdinirwanto, 
2013). The result of the $\mathrm{N}$-gain understanding of the experiment class concept was higher than the control class. This shows the use of video tracking software was acceptable to learners and effective for learning. Differences in concepts test results also showed significant value so that the use of video tracker software can be used for further learning. This corresponds to the conclusion.

\section{Conclusion}

Based on data analysis about the understanding of physics concepts with the use of video tracker shows a significant difference from the control class, so it can be concluded that the use of effective video tracker is used to understand the concept of physics. Increasing the gain value in the experimental class reinforces the hypothesis about the effective use of video trackers in physics learning. Student responses generally show good interest and responsiveness to the use of video trackers.

Some suggestions for improving our learning are that (1) tracker usage can be used in physics practice related to position, speed and time so that it can be a reference for other materials; (2) in the next learning utomatic tracker can be used as video tracker used in this research is the manual one.

\section{References}

Anugrahaini, U. S., S. E. Nugroho, and A. Yulianto. (2017). Analisis Kemampuan Berpikir Kritis dan Kreatif pada Penyusunan Laporan Praktikum Fisika Dasar, Phys. Commun., 1(1). 49-59.

Setyorini, U., S. E. Sukiswo, and B. Subali. (2012). Penerapan Model Problem Based Learning Untuk Smp. Indonesian J. Phys. Education. 8(1). $52-56$.

Riyadi, A. and M. Mosik. (2014). Penerapan Metode Pembelajaran Kooperatif Tipe Nht Untuk Meningkatkan Pemahaman Konsep Dan Komunikasi Ilmiah. Unnes Phys. Educ. J., vol. UPEJ 3(2). Retrieved from http://journal.unnes.ac.id/sju/index.php/ upej, 2014.

Linuwih, S. and N. O. E. Sukwati. (2014).
Efektivitas Model Pembelajaran Auditory Intellectually Repetition (AIR) Terhadap Pemahaman Siswa Pada Konsep Energi Dalam. $J$. Pendidik. Fis. Indonesia, 10(2). 158162.

Wahyuni, S. (2015). "Developing Science Learning Instruments Based On Local Wisdom To Improve Student's Critical Thinking Skills Pengembangan," $J$. Pendidik. Fis. Indonesia, 11(2).

Brown, D. and W. Christian. (2011). Simulating what you see: Combining computer modeling with video Modeling. Mptl 16-Hsci 2011.

M. \& M. Habibulloh. (2014). Penerapan Metode Analisis Video Software Tracker Dalam Pembelajaran Fisika Konsep Gerak Jatuh Bebas Untuk Kelas X Sman 1 Sooko Mojokerto Meningkatkan Keterampilan Proses Siswa. 4(1). 15-22.

Karsumi. (2012). Pengembangan alat praktikum viskosimeter zat cair. $J$. Pendidik. (Indonesian J. Phys. Educ., 8 (1). 8-14.

Fuller., G. G. (1987). "Extensional Viscosity Measurements for Low-Viscosity Fluids," J. Rheol. (N. Y. N. Y). 31(3). 235.

R. \& S. Oktova. (2013). Pemanfaatan Tracker Dalam Eksperimen Ayunan Bandul Teredam Untuk Penentuan Koefisien Viskositas Udara Dengan Hukum Landau-Lifshitz. (Indonesian Journal Phys. Educ. 5 (1986). 43-59.

Qudsi, I. (2014) Pembelajaran Tutor Sebaya Materi Besaran Dan Satuan Fisika. Dinamika 4(3).

Kaewsutthi, C. and P. Wattanakasiwich. (2011). Student Learning Experiences From Drag Experiments Using HighSpeed. 181-186.

Prasetyarini, A., S. D. Fatmaryanti, and R. W. Akhdinirwanto. (2013). Pemanfaatan Alat Peraga IPA untuk Peningkatan Pemahaman Konsep Fisika pada Siswa SMP N 1 Buluspesantren, Kebumen Tahun Pelajaran 2012/2013. Radiasi, 2(1). 7-10. 